\title{
超高齢社会におけるフレイル概念の重要性と 診断および対処方法
}

\author{
佐竹 昭介 ${ }^{1)}$ 荒井 秀典 ${ }^{2}$
}

\section{抄 録}

高齢者の健康問題を考える時、疾患のみならず、心身機能の衰えを視野に入れる必要がある。兴こには、体力 や気力の低下という老いに伴う問題が存在している。これらの問題の重要性は、75歳以後の要介護の原因が、加 齢に伴う衰弱などの疾患概念では捉えにくい問題が主因となってくることからも明らかである。日本老年医学会 は、加齢に伴う衰えを「フレイル」と表現することを提唱し、兴の積極的な予防対策により自立障害に至る過程 を遅らせる重要性を説いている。

フレイルの捉え方には大きく2つの考え方があり、加齢に伴う障害や生活機能障害、疾患などの蓄積を評価す ることでフレイルを捉える「障害蓄積モデル」と、加齢に伴う生体機能の低下により表出してくる症候を捉える 「表現型モデル」がある。いずれの評価でも、将来の健康障害発生を予測することが可能であり、フレイルは高 齢者の健康評価には不可欠な視点になっている。しかし、关の評価方法は一つに定まっておらず、多数の評価方 法が存在しているのが現状である。

フレイルの予防対策は、バランスの良い栄養摂取と運動習慣の確立というライフスタイルに関わる改善が主体 である。栄養では、従来よりも積極的な蛋白質摂取が推奨されるようになっている。運動では、筋肉の衰えを改 善しうるレジスタンス運動が推奨されるが、フレイル高齢者にとっては、歩行を含めた運動習慣の獲得が重要と 思われる。

高齢者における自立障害の予防が、健康長寿社会には重要であり、フレイルという概念を取り入れることで、 兴の実現に寄与しうることが期待されている。

(総合健診. $2017 ; 44: 370-377$.)

キーワード＼cjkstart表現型モデル、障害蓄積モデル、サルコペニア、低栄養、筋蛋白同化抵抗性

\section{ヤ〉はじめに}

高齢者医療は包括的・全人的医療であり、臟器別 医療とは異なるパラダイムに属している。高齢者は 複数の疾患を併せ持つことが多いことに加え、加齢 に伴う身体機能の低下が潜在し、若年者における経 過や症候とは異なる病態をしばしば呈する。このた め、臟器別の疾患概念や治療指針だけでは高齢者の 健康管理はうまくいかない。

我々の心身の状態を「健康」と「障害」という概 念で捉えた時、若年者の中で「障害」に至る危険の 高い人は、「何らかの疾患を有する人 (有病者)」で

1 ）国立研究開発法人国立長寿医療研究センター老年学・ 社会科学センターフレイル研究部フレイル予防医学研 究室

2 ) 国立研究開発法人国立長寿医療研究センター老年学・ 社会科学センター
ある。しかし、高齢者の場合、「障害」に陥る危険 が高くなるのは、必ずしも疾患を有する人ばかりで はなく、疾患概念で捉えきれない、身体機能低下や 精神的疲労を有する人々も存在している。このよう な障害を起こしやすいハイリスク高齢者を、「健康」 と「障害」の中間に位置付ける視点が重要になって いる。

我が国では従来、そのようなハイリスク高齢者の 一部を「虚弱」や「老衰」という言葉で表現してい た。しかし、これらの用語は「歳のせい」という不 可逆的なマイナスイメージを含み、積極的な予防を 推進する意識改革には用語の改訂が必要ということ になった。これを受けて、2014年 5 月、日本老年医 学会は、「老衰」や「虚弱」と呼ばれた加齢に伴う 衰えを、「フレイル」という用語に統一する声明を 発表した11。フレイルとは、ストレスに対する回復 力が低下した状態を示す “frailty”を、日本語の語 


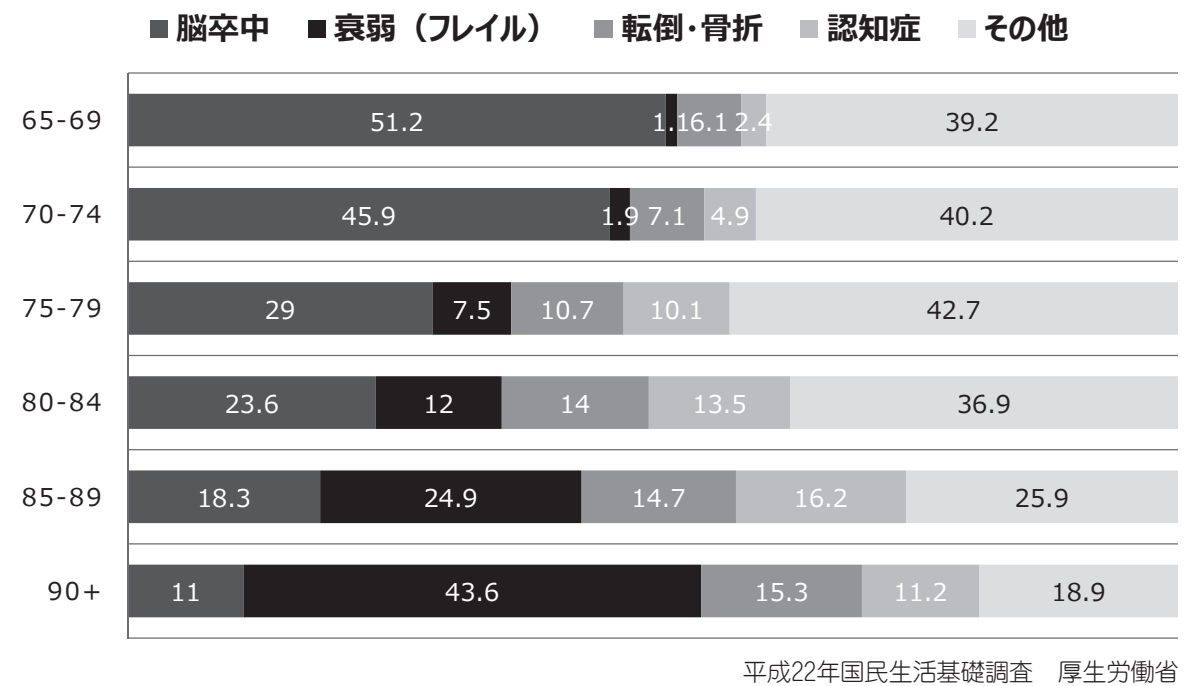

感にも配慮し、その形容詞型である“frail”をその ままカタカナ表記にしたものである。

フレイルの概念が超高齢社会で重要な理由は、75 歳以上の後期高齢者における要介護の主な原因が、 加齢に伴う衰弱、すなわちフレイルに置き換わって いくためである (図 1 $)^{2)} 。 2014$ 年10月の統計によれ ば、我が国における65歳以上の高齢者は3,300万人 (26.0\%) に達しており、そのうち75歳以上の後期 高齢者は国民の約 8 人に 1 人 $(12.5 \%)$ を占めてい $3^{3)}$ 。平均寿命も男性80.21歳、女性86.61歳という 世界トップレベルの超高齢社会に突入した我が国で は、高齢後期までの人生を視野に入れた健康管理が 必要となっている。

このように、健康長寿社会の実現を目指すために は、フレイルという概念が重要な役割をもってお り、その予防や対策に注目が集まっている。

\section{ヤ フレイルの概念}

フレイルは、臨床的には脆弱な高齢者を表現する 用語であり、よく見られる状態であるにもかかわら ず、学術的に定義することは困難であった。2004年 と2006年に行われた「フレイルと加齢に関する国際 会議」では、「フレイルとは相互に関連する複数の 生理系を調節する恒常性維持機構の衰えのため、些 細なストレスにより障害を受けやすい脆弱な状態で ある」と表現されることになった4)。

この状態は、図 2 のようなモデルで説明されてい

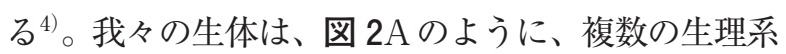
が存在し、個々の生理系の中には常にバランスが保
図 2 フレイルの概念モデル ${ }^{4}$
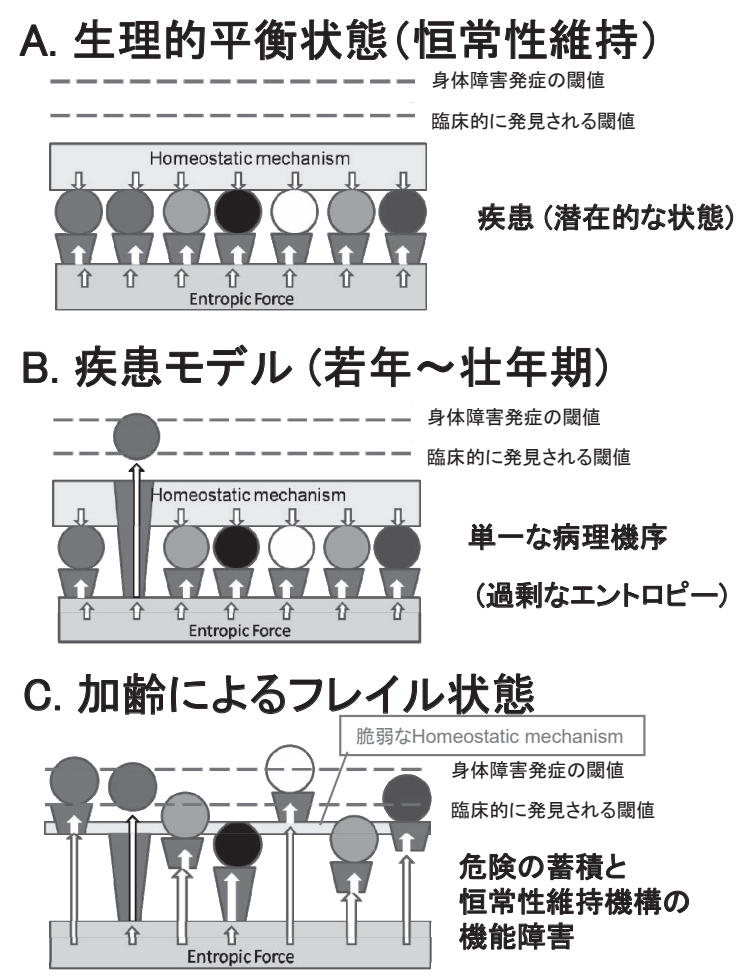

* Homeostatic mechanismが身体機能を制御できない状態であるため 一つの系へのストレスに起因して、複数の障害が引き起こつている。

たれている。そして、そのバランス障害が生じると 疾患が表在化し、生理系が破綻を来すことになる。 このような生理系は、生体の中で調和をもって生命 活動を営んでいるが、それを制御しているのが、恒 常性維持機構である (Homeostatic mechanism)。 生体は恒常性維持機構により、様々な多数の系を統 合して個体としての生命の営みを可能にしている。 健康な状態では、恒常性維持機構が個々の生理系を うまく調和させバランスを保っているが、疾患が発 
症する際にはそのバランスが崩れる。若年者では、 疾患が一つの生理システムに一定の破綻をもたらし ても、一般に、その他の多数の系は崩れることなく 恒常性を維持し生命の営みを続けることができる (図 2B)。しかしフレイル高齢者は、若年者の場合 とは異なり、一つの系の障害に留まらず、複数の系 に損傷が起こり、臨床症状や障害として表在化する (図 2C)。これは複数の系にまたがる恒常性維持機 構が脆弱化したため、ストレスによる障害を受けや すく回復しづらい状況になるためである。このよう な状態が、フレイルであると考えられている。

\section{$\gg$ フレイルの診断}

フレイルの捉え方は、「加齢に伴ってもたらされる 有害事象の誘因となる疾患、生活動作障害、身体活 動障害の集積」と捉える「障害蓄積モデル（accumulated deficit model) 」5) と、「加齢に伴う、さまざま な生理システムの機能低下から表出される徵候の集 積」と捉える「表現型モデル (phenotype model) 」4) に分けられ、前者はRockwood らのグループが提唱 し、後者は Fried らが提唱した考え方である。

現在のところ、フレイルの診断として統一された 基準はなく、学術論文としては「表現型モデル」に 準じた基準を用いたものが 7 割弱を占めている。し かし、フレイルは身体的な問題のみならず、心理 的、社会的な側面も持ち合わせているため、これら の評価を含む総合機能評価を重視する考え方もあ る。これに対し、「表現型モデル」は身体的機能評 価が主体となるため、身体的フレイルの評価法と位 置付けられている。また、さまざまなスクリーニン グ法が提案されており、それぞれの方法の有用性も 検証されている。

\section{1 ) 障害蓄積モデル}

カナダの Rockwood らは、フレイルとはさまざま な身体能力、疾患、生活機能などの困難性や障害の 積み重ねにより生じるものと考えた5)。そして、日 常生活動作、健康度、併存症、身体能力などを包括 的に含めた総合的な評価方法として、機能的な障害 や異常所見の数を重みづけすることなく加え、全体 の評価項目数で除した Frailty Index を用いること の妥当性を示した。同じ年齢であれば、男性に比べ 女性の方が Frailty Index は高いが、同じ Frailty Index で比較すると男性で死亡率が高い。Frailty Index が高いほど死亡率は高く、表現型モデルと相
图 3 フレイルの状態と生存曲線

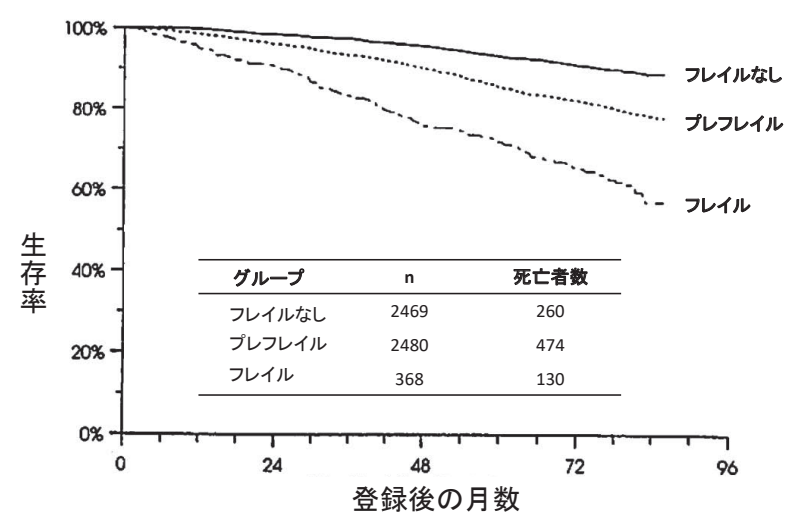

関性があることも検証されている6)。

\section{2 ) 表現型モデル}

Fried らは、加齢に伴う衰えとして表出される徵 候を、フレイルの表現型（phenotype of frailty）と して、(1)動作の緩慢さ（歩行速度の低下）、(2)筋力 の低下、(3)活動性の低下、(4)倦㤐感・疲労感、(5)体 重減少の 5 つに集約されると考えた4)。そして、そ のうち 3 つ以上を有する場合にフレイル状態と考 え、 1 つまたは 2 つに該当する場合はプレフレイル と評価するのが妥当であるとした。Fried らは、米 国の地域在住高齢者約5,000名を対象とした Cardiovascular Health Study（CHS）において、このフレ イル評価が将来的な生活機能障害や生命予後に有意 な影響を及ぼすことを示し、フレイル評価の妥当性 と有用性を明らかにした（図 3$)^{7)}$ 。

\section{3 ）その他のフレイル評価法}

\section{(1)Clinical Frailty Scale (CFS)}

カナダの加齢と健康調查 (Canadian Study of Health and Aging) において用いられた評価方法で ある。特殊な計測を必要とせず、患者の健康情報を 基に臨床的判断を行い、壮健、健常、健康管理しつ つ元気な状態を維持、脆弱、軽度のフレイル、中等 度のフレイル、重度のフレイル、非常に重度のフレ イル、疾患の終末期、の 9 段階に分類する ${ }^{8)}$ 。シル エットイメージと簡単な説明書きが付記されている ため、評価にはさほど時間を要しない。簡便である ため、外来や入院など多くの場面で利用できるフレ イル診断法として 1st line に位置付けられる。

\section{(2)FiND Questionnaire (Frail, Non-Disabled)}

この質問票では、身体障害 (移動能力の障害等) をフレイルと区別しており、400m の歩行が困難で あるか、踊り場までの階段を昇ることができない場 合に身体障害ありと評価している9)。この 2 つに問 
題がない場合、(1)意図しない体重減少が 1 年間に $4.5 \mathrm{~kg}$ 以上ある、(2)何をなすにもおっくうで、なす べきことに取りかかれないことが週に 3 回以上あっ た、(3ほとんどじっとしていることが多い、の3つ のいずれかに該当する場合にフレイルと評価する99。

(3) Gérontopôle Frailty Screening Tool (GFST)

フランスの Gérontopôle (Frailty Clinic) で開発 された、一般診療医 (GP) 向けの評価票である ${ }^{9)}$ 。 地域の GPがこのGFST 用いてフレイルを評価し、 更なる評価や介入が必要と判断すれば、day hospital (Gérontopôle) での評価を推奨する。GFST は 近年、フランスに打ける高齢者のフレイルスクリー ニング法として the French National Authority for Health に承認された。

この評価法の対象者は、身体障害がなく、急性疾 患を発症していない65歳以上の高齢者で、第 1 段階 では、独居、体重減少、倦总感、移動性、記銘力、 動作性のそれぞれについて障害の有無の評価を行 う。そして一つでも該当した場合、第 2 段階とし て、評価者 (GP) 自身が、被験者をフレイルと考え るか否かを臨床的に判定する。この評価方法によっ て判定をされ、 day hospital (Gérontopôle) 一紹介 をされた患者 442 名のうち、 $95.2 \%$ が $\mathrm{CHS}$ 基準のプ レフレイルかフレイルに相当したことが報告されて いる9)。

\section{(4)FRAIL scale}

これは、「FRAIL」の各頭文字をとり、F：Fatigue (倦总感)、 $\mathrm{R}$ : Resistance (筋力)、A：Aerobic (有 酸素運動)、I : Illness (疾患)、L : Loss of weight (体重減少) の 5 項目について評価し、3つ以上該 当する場合はフレイル、1-2つに該当する場合はプ レフレイル、いずれにも該当しない場合に壮健と分 類する方法で、将来的な ADL (Activities of Daily Living）や手段的 ADL の低下、死亡率の上昇との 関連性も確認されている ${ }^{10)}$ 。

\section{(5)基本チェックリスト（KCL)}

KCL は、2006年の介護保険制度の改定の際に、近 い将来介護が必要になる高齢者を抽出するスクリー ニング法として、厚生労働省の研究班によって開発 された。対象者は、認知症や身体障害による要介護 状態にない高齢者を想定しており、population approach を目的とした介護予防事業及び高齢者定 期健康診断の一環として導入された。KCLの質問 は、生活機能状態を尋ねる25個の質問からなり、 「はい・いいえ」で回答するものである。その質問
項目は 7 つの領域にわたり、IADL（\#1-5)、身体機 能 (\#6-10)、栄養状態 $(\# 11,12)$ 、口腔機能 (\#1315)、閉じこもり $(\# 16,17)$ 、認知機能 $(\# 18-20)$ 、 気分（\#21-25）について総合的に機能評価ができ、 回答時間も10 15分程度であるため、外来の待ち時 間に実施することも可能である。KCLは、横断的・ 縦断的な研究で、フレイル評価としての有用性が検 証されている11)。

\section{(6)Frailty Screening Index (FSI)}

FSI は、CHS 基準に基づいて開発された 5 項目の 自記式質問票であり、筋力低下の代わりに認知機能 評価が含まれ、体重減少と倦怠感に関する質問は、 基本チェックリストの質問を用いている。該当項目 数によるカテゴリー分類は、CHS 基準に準じる。 5,852 名の地域在住高齢者を対象にした調查で、2 年後の自立機能低下と有意に関連することが報告さ れている12)。

\section{(7)Edmonton Frail Scale (EFS)}

EFSには、認知機能評価としての時計描画テスト と、身体機能評価としての Timed Up and Go test が含まれ、加えて健康状態の自己評価、手段的生活 活動度、薬剂、栄養、抑うつ、失禁に関する質問が 加えられている ${ }^{13)}$ 。 EFS は10分内で完了できるとさ れ、さまざまな診療場面で用いられる。

\section{(8) Study of Osteoporotic Fractures (SOF) Index}

SOF は、脚力、体重減少㧍よび倦急感の 3 項目で フレイル状態を評価し、いずれにも該当しない場合 を壮健、いずれか 1 つ該当した場合をプレフレイ ル、2つ以上該当した場合をフレイルと評価する。 この方法と CHS 基準を比較したコホート調査では、 死亡、繰り返す転倒、骨折などの健康障害に対する 予後予測は、概ね同等であったことが報告されてい る $^{14)}$ 。

\section{$\mapsto$ フレイルの予防と対処法}

\section{1 ) フレイルと栄養}

イタリアの InCHIANTI Study では、802人の65 歳以上の高齢者を対象として、フレイルの有無と栄 養摂取状況の関連が横断調查として解析された ${ }^{15)}$ 。 フレイルと関連した栄養素は、蛋白質摂取不足以外 に、抗酸化ビタミン (ビタミン C P E )、ビタミン D、葉酸などであった（表 1 ）。蛋白質摂取不足は、 フレイルの中核病態であるサルコペニアの発症や増 


\begin{tabular}{|c|c|c|c|c|}
\hline \multirow{2}{*}{ 摂取栄養素 } & \multicolumn{2}{|c|}{ エネルギー量調整なし } & \multicolumn{2}{|c|}{ エネルギー量調整あり } \\
\hline & OR $(95 \% \mathrm{Cl})$ & $p$ & OR $(95 \% \mathrm{Cl})$ & $p$ \\
\hline 蛋白質（g/日） & $1.75(1.12-2.73)$ & 0.014 & $1.98(1.18-3.31)$ & 0.009 \\
\hline 鉄 $(\mathrm{mg} /$ 日) & $1.37(0.87-2.14)$ & 0.174 & $1.45(0.85-2.47)$ & 0.171 \\
\hline カルシウム (mg/日) & $1.31(0.83-2.07)$ & 0.242 & $1.32(0.81-2.14)$ & 0.266 \\
\hline ビタミン D ( $\mu \mathrm{g} /$ 日 $)$ & $2.27(1.45-3.53)$ & 0.002 & $2.35(1.48-3.73)$ & 0.001 \\
\hline ビタミン E (mg/日) & $1.96(1.25-3.07)$ & 0.004 & $2.06(1.28-3.33)$ & 0.003 \\
\hline ビタミン A $(\mu \mathrm{g} / \theta)$ & $1.57(0.99-2.47)$ & 0.053 & $1.56(0.99-2.48)$ & 0.057 \\
\hline ビタミン C (mg/日) & $2.12(1.34-3.36)$ & 0.001 & $2.15(1.34-3.45)$ & 0.001 \\
\hline 葉酸（ $\mu \mathrm{g} /$ 日） & $1.76(1.12-2.75)$ & 0.014 & $1.84(1.14-2.98)$ & 0.013 \\
\hline 覀鉛 （mg/日） & $1.04(0.64-1.68)$ & 0.887 & $1.01(0.61-1.67)$ & 0.969 \\
\hline
\end{tabular}

（年齢、性、教育、経済状態、世帯構成、喫煙状態、疾患数、MMSE、BMI、幸福感、で調整）

悪とも関連することが明らかにされている。

\section{(1)観察研究}

フレイルの中核病態として注目されているサルコ ペニアは、近年、骨格筋における筋蛋白同化抵抗性 (Anabolic resistance) が原因の一つとして指摘さ れている。これまでの研究によれば、筋蛋白合成刺 激は加齢に伴い鈍くなり、ある一定以上の刺激がな いと蛋白合成が活性化しない16)。米国で行われた Health ABC Study において、蛋白質摂取量が少な いほど将来的な除脂肪体重の減少が大きいことが報

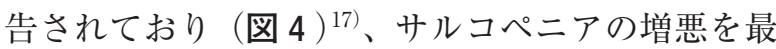
小限にするためにも、十分な蛋白質の摂取が重要で あることが明らかになってきた。

蛋白質摂取とフレイルの関連性については、米国 の約24,000名の女性を対象とした調査において、摂 取エネルギー当たりの蛋白質摂取比率が高い群では フレイルの発症率は低く、低い群ではフレイルの発 症率が高いことが報告されている18)。我が国でも約 2,000名の高齢女性を対象とした多施設横断研究が あるが、この報告では、蛋白質摂取総量が高いほ ど、フレイルの発症率は低いと結論づけている ${ }^{19)} 。$

ビタミン D に関する観察研究では、低ビタミン D 血症が筋肉量の減少と関連性があること、とくに II 型の筋肉繊維が萎縮することが報告をされてお り 20)、ビタミン D の不足がサルコペニアの発症に関 連することが示唆されている。フレイルとビタミン Dの関連性についてもいくつかの報告があり、概し てビタミン D の不足はフレイルと関連するという報 告が多い21)。

近年は、個々の栄養素摂取よりも、栄養のバラン ス（質）が良いとフレイルの発症率が低いことが注

\section{図4摄取蛋白質量と除脂肪体重の変化 ${ }^{17}$}

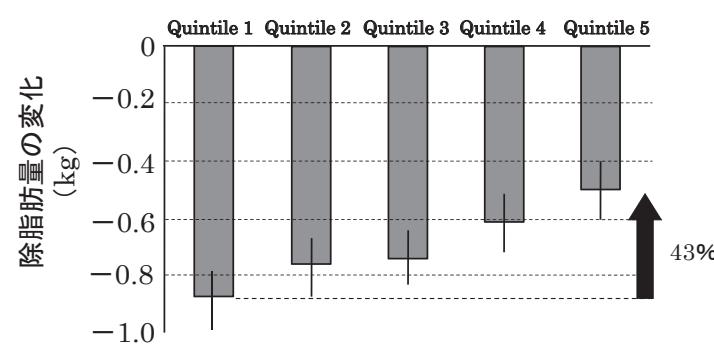

㩒取タンパク質の割合 $\quad 11.2 \% \quad 12.7 \% \quad 14.1 \% \quad 15.8 \% \quad 18.2 \%$ $\begin{array}{llllll}\text { 総タンパク質摂取量 } & 0.7 & 0.7 & 0.8 & 0.9 & 1.1\end{array}$ ( $\mathrm{g} / \mathrm{kg} /$ day)

目され、地中海食ピラミッドに近い摂取パターンで はフレイルの危険が低いと報告されている22)。

\section{(2)介入研究}

蛋白質を積極的に摂取することで、身体機能の改 善が得られるか否かを調査した無作為介入試験が報 告されている23)。フレイルまたはプレフレイル高齢 者に対し、1 日 $30 \mathrm{~g}$ の蛋白質を含む補助栄養㓮を摂 取したグループと、同等のカロリーのプラセボを摂 取したグループに分け、6か月後に評価したとこ ろ、蛋白質の含まれている補助栄養剤を摂取したグ ループでは、筋肉量には有意な改善が見られなかっ たものの、椅子からの立ち上がり機能が改善し、身 体機能が改善していた。

また、この研究チームは、レジスタンス運動介入 をしているプレフレイル、またはフレイル高齢者に 対し、蛋白質を含む補助栄養剤と、同等のカロリー のプラセボを投与し、前述と同じ評価を半年後に 行ったところ、いずれのグループも身体機能の改善 が見られ、蛋白質の含まれる補助栄養剤を摂取した グループでは、筋肉量の増加が有意であったことを 
示した ${ }^{24)}$ 。

ビタミン D をホエイ蛋白と一緒に投与した RCT が近年報告された ${ }^{25)}$ 。これは多施設による共同研究 で、対象者は身体機能が低下し (SPPB: Short Physical Performance Battery 4 9)、筋肉量も低 下したサルコペニアを有する高齢者であった。介入 群には $20 \mathrm{~g}$ のホエイ蛋白、3g のロイシン、 $9 \mathrm{~g}$ の糖 質、3g の脂質、そして $800 \mathrm{IU}$ のビタミン D が含ま れた栄養補助剤が投与され、対照群には蛋白質とビ タミンを含まない等カロリーの栄養補助剤が投与さ れた。13週の介入の結果、筋肉量と下肢筋力は介入 群で有意に改善されていた。

\section{2 ) フレイルと運動}

\section{(1)運動習慣への介入と筋肉機能}

生活習慣への介入試験としては、70～89歳までの 非活動的な生活習慣を有する高齢者 424 名を対象と した報告がある ${ }^{26)}$ 。この試験では、フレイル高齢者 の一群と考えられる非活動的で障害の危険のある高 齢者を対象としている。非活動的生活習慣とは、1 週間に系統だった 20 分以上の運動を行わない生活習 慣とし、身体機能障害の危険とは、SPPBの得点が 9 点以下であるが 15 分以内に $400 \mathrm{~m}$ 以上歩行が可能 な状態、と定義している。介入群では、開始 2 ヶ月 間は週に 3 回の運動教室への参加を義務付け、その 後〜 6 ケ月は週に 2 回の運動教室 +家庭での運動指 導（週に 3 回以上)、そして半年以後は家庭での運 動を主体とし、運動教室は週に1-2回と漸減して継 続維持とするプロトコールになっている。家庭での 運動は、週に150分以上の運動を指導し、基本的に は散歩を推奨している。非介入群は、健康指導とし て26週までは週に 1 回の指導教室を行い、その後は 月に 1 回の頻度で健康教室への参加を促した。この ような介入試験の結果、 1 年後の SPPB、 $400 \mathrm{~m}$ 歩行 速度の改善が介入群で有意に改善されたことが報告 された。解析の中では、年齢、性別、人種、SPPB 得点、併存症の数などでサブグループに分けて評価 されているが、同様の改善傾向が見られた（図 3)。

(2)運動とアミノ酸摄取による介入と筋肉量、筋肉 機能

金らは、サルコペニアと診断された155名の高齢 女性を対象に、運動（レジスタンストレーニング）+ アミノ酸群、運動群、アミノ酸群、健康指導群の 4 群に無作為割付を行い 3 ヶ月間の介入を行った ${ }^{27) 。 ~}$ 下肢筋肉量、歩行速度、膝進展筋力のうちの一部 は、運動群やアミノ酸群でも改善が認められたが、
すべての項目で有意な改善が認められたのは、運動 +アミノ酸群のみであった。また、多重ロジス ティック回帰分析による介入効果の検討において、 筋肉量と筋肉機能 (膝進展筋力あるいは歩行速度) の改善が有意に認められたのは、やはり運動+アミ ノ酸群のみであり、他の群では有意差が見出されな かった。この結果は、アミノ酸 (ロイシン) と運動 （レジスタンストレーニング）の併用が、蛋白同化 刺激作用を増強するとともに、筋肉の質的な改善を もたらす可能性を示唆している。

\section{$\gg$ おわりに}

超高齢社会を迎えた我が国では、健康長寿が重要 な課題であり、加齢に伴う身体機能低下や自立障害 の危険を警鐘する「フレイル」という概念が必要不 可欠である。フレイル高齢者への予防介入として は、栄養や運動などのライフスタイルが重要である ことが科学的な手法により示されており、生活に導 入しやすく継続しやすい方法を考案していくことが 課題になっている。

すべての生命はやがて土に帰るという宿命を持っ て生まれる。加齢に伴う変化もまた、不可避な宿命 の一つであるが、老化の進行はさまざまである。高 齢者の尊厳に配慮した健康長寿を目指す社会では、 老化の進行を遅らせ、自立障害を最小限にして行く 努力が、老年学や高齢者医療に求められている。フ レイルという視点は、その一つのきっかけである。

著者の COI (conflict of interest) 開示: 本論文発表内容 に関連して特に申告なし

\section{$\rightarrow$ 引用文献}

1) 日本老年医学会：フレイルに関する日本老年医学会から のステートメント. (オンライン) 入手先〈http://www. jpn-geriat-soc.or.jp/info/topics/pdf/20140513_01_01. $\mathrm{pdf}\rangle, \quad($ 参照2016-8-5)

2) 厚生労働省：高齢者リハビリテーション研究会資料 7 . (オンライン) 入手先〈http://www.mhlw.go.jp/shingi/ 2004/02/s0223-8h.html〉, (参照2016-8-5)

3) 内閣府: 第 1 節高齢化の状況 平成 27 年版高齢社会白 書 (概要版). (オンライン) 入手先〈http://www8.cao. go.jp/kourei/whitepaper/w-2015/gaiyou/pdf/1s1s.pdf〉, (参照2016-8-5)

4) Fried LP, Walston JD, Ferrucci L: Frailty. Hazzard's Geriatric Medicine and Gerontology. ed. by Haltar J. 
B. et al. 6th ed, USA, McGraw Hill, 2009, 631-45.

5 ) Rockwood K, Mitnitski A: Frailty in relation to the accumulation of deficits. J Gerontol A Biol Sci Med Sci 2007 Jul; $62(7)$ : 722-7.

6 ) Mitnitski AB, Song X, Rockwood K: The estimation of relative fitness and frailty in community-dwelling older adults using self-report data. J Gerontol A Biol Sci Med Sci 2004 Jun; 59(6): M627-32.

7 ) Fried LP, Tangen CM, Walston J, et al: Frailty in older adults: evidence for a phenotype. J Gerontol A Biol Sci Med Sci 2001 Mar; 56(3): M146-56.

8 ) Dalhousie University. Geriatric Medicine Research. Clinical Frailty Scale. (オンライン) 入手先 〈geriatricresearch.medicine.dal.ca/clinical_frailty_scale. htm $\rangle$, (参照2016-9-2)

9 ) Vellas B: Implementing frailty screening, assessment, and sustained intervention: the experience of the Gérontopôle. J Nutr Health Aging. 2015; 19: 673-80.

10) Morley JE, Malmstrom TK, Miller DK: A simple frailty questionnaire (FRAIL) predicts outcomes in middle aged African Americans. J Nutr Health Aging 2012 Jul; 16(7): 601-8.

11) Sewo Sampaio PY, Sampaio RA, Yamada M, et al: Systematic review of the Kihon Checklist: is it a reliable assessment of frailty? Geriatr Gerontol Int 2016; 16: 893-902.

12) Yamada M, Arai H: Predictive value of frailty scores for healthy life expectancy in community-dwelling older Japanese adults. J Am Med Dir Assoc 2015; 16: 1002. e7-11.

13) Rolfson DB, Majumdar SR, Tsuyuki RT, et al: Validity and reliability of the Edmonton Frail Scale. Age Ageing 2006 Sep; 35(5): 526-9.

14) Ensrud KE, Ewing SK, Taylor BC, et al: Comparison of 2 frailty indexes for prediction of falls, disability, fractures, and death in older women. Arch Intern Med 2008 Feb 25; 168(4): 382-9.

15) Bartali B, Frongillo EA, Bandinelli S, et al: Low nutrient intake is an essential component of frailty in older persons. J Gerontol A Biol Sci Med Sci 2006 Jun; 61 (6): 589-93.

16) Rasmussen BB, Volpi E: Muscle biology and mTORC1 signaling in aging. ed. by Cruz-Jentoft AJ, Morley JE, Sarcopenia, 1st ed, West Sussex: Wiley-Blackwell, 2012.

17) Houston DK, Nicklas BJ, Ding J, et al: Dietary protein intake is associated with lean mass change in older, community-dwelling adults: the Health, Aging, and Body Composition (Health ABC) Study. Am J Clin
Nutr 2008 Jan; 87 (1): 150-5.

18) Beasley JM, LaCroix AZ, Neuhouser ML, et al: Protein intake and incident frailty in the Women's Health Initiative observational study. J Am Geriatr Soc 2010 Jun; 58(6): 1063-71.

19) Kobayashi S, Asakura K, Suga H, Sasaki S: High protein intake is associated with low prevalence of frailty among old Japanese women: a multicenter cross-sectional study. Nutr J 2013; 12: 164.

20) Ziambaras K, Dagogo-Jack S: Reversible muscle weakness in patients with vitamin D deficiency. West J Med 1997 Dec; 167 (6): 435-9.

21) Wong YY, McCaul KA, Yeap BB, Hankey GJ, Flicker L: Low vitamin D status is an independent predictor of increased frailty and all-cause mortality in older men: the Health in Men Study. J Clin Endocrinol Metab 2013 Sep; 98(9): 3821-8.

22) Bollwein J, Diekmann R, Kaiser MJ, et al: Dietary quality is related to frailty in community-dwelling older adults. J Gerontol A Biol Sci Med Sci 2013 Apr; 68(4): 483-9.

23) Tieland M, van de Rest O, Dirks ML, et al: Protein supplementation improves physical performance in frail elderly people: a randomized, double-blind, placebo-controlled trial. J Am Med Dir Assoc 2012; 7206.

24) Tieland M, Dirks ML, van der Zwaluw N, et al: Protein supplementation increases muscle mass gain during prolonged resistance type exercise training in frail elderly people: a randomized, double-blind, placebocontrolled trial. J Am Med Dir Assoc 2012; 713-9.

25) Bauer JM, Verlaan S, Bautmans I, et al: Effects of a vitamin $\mathrm{D}$ and leucine-riched whey protein nutritional supplement on measures of sarcopenia in older adults, the PROVIDE Study: Randomized, double-blind, placebo-controlled trial. J Am Med Dir Assoc 2015; 7407.

26) Pahor M, Blair SN, Espeland M, et al: Effects of a physical activity intervention on measures of physical performance: Results of the lifestyle interventions and independence for Elders Pilot (LIFE-P) study. J Gerontol A Biol Sci Med Sci 2006 Nov; 61(11): 115765.

27) Kim HK, Suzuki T, Saito K, et al: Effects of exercise and amino acid supplementation on body composition and physical function in community-dwelling elderly Japanese sarcopenic women: a randomized controlled trial. J Am Geriatr Soc 2012 Jan; 60 (1): 16-23. 


\title{
Importance of Frailty Concept in a Superaged Society, and its Diagnosis and Management
}

\author{
Shosuke Satake ${ }^{1)}$, Hidenori Arai $^{2)}$ \\ 1) Section of Frailty Prevention, Department of Frailty Research, Center for Gerontology and Social Sciences, \\ National Center for Geriatrics and Gerontology \\ 2) Center for Gerontology and Social Sciences, National Center for Geriatrics and Gerontology
}

\begin{abstract}
In geriatric practice, primary care physicians or geriatricians need to consider not only diseases but also age-dependent impairment in their physical and mental functions to keep their health. This is obvious because frailty, which is difficult to be understood by disease-based concept, occupies large part of the cause of dependency in the old-old population. Therefore, the Japan Geriatric Society proposed a new expression of frailty as "Frail" in Japanese, and advocated that appropriate prevention of "Frail" is important to postpone the process toward disability.

There are two representative models to capture frailty, such as the accumulated deficit model by Rockwood et al. and the phenotype model by Fried et al. The previous studies indicated that both models could predict the incident adverse health outcomes. These studies support that frailty is an important concept in geriatric medicine. However, frailty assessment is not unified yet, therefore a lot of screening tools and assessments of frailty do exist at present.

The important preventive measures are to support an intake of balanced foods and regular exercises in daily lives for frail older adults. Recently, a higher protein-intake is recommended for older adults to keep their muscle mass in the nutrition field. In terms of physical exercise, resistance training is thought to be beneficial for preventing muscle weakness but the acquiring the habit of regular exercise may be more important for frail seniors.

Frailty has been the center of geriatrics because it could be an effective concept for identifying the pre-disability state with reversibility which may be the best for preventive intervention. The concept of frailty is thought to be necessary for the healthy longevity.
\end{abstract}

(HEP. 2017;44:370-377.)

\section{KEY WORDS Phenotype model, Deficit model, Sarcopenia, Undernutrition, Anabolic} resistance 